\title{
Fibrous Monolithic Ceramics: IV, Mechanical Properties and Oxidation Behavior of the Alumina/Nickel System
}

\author{
Suresh Baskaran, ${ }^{* \dagger}$ Stephen D. Nunn, ${ }^{*, \neq}$ and John W. Halloran ${ }^{*}$ \\ Department of Materials Science and Engineering, University of Michigan, \\ Ann Arbor, Michigan 48109-2136
}

\begin{abstract}
Fibrous monolithic ceramics were fabricated in the alumina/nickel system. The microstructure consists of highaspect-ratio polycrystalline cells of alumina separated by thin cell boundaries of nickel. The nickel content in the material is 3 to $8 \mathrm{vol} \%$. The fibrous monolith with uniaxially aligned cells fails noncatastrophically in flexure. Bridging ligaments of nickel, crack deflection along cell boundaries, and crack branching in the axial direction are observed in flexure bars and notched beams. Strength values range from 246 to $375 \mathrm{MPa}$. Indentations cause controlled damage on the surface but do not introduce strength-degrading flaws. The alumina/nickel fibrous monoliths also show potential for use at high temperatures in oxidizing environments. Noncatastrophic fracture behavior is observed at room temperature after $10 \mathrm{~h}$ at $1200^{\circ} \mathrm{C}$ in air. The $\mathrm{Ni}$ cell boundary network is oxidized to a depth of 50 to $100 \mu \mathrm{m}$ by this heat treatment. The $\mathrm{NiO}$ oxidation product in the cell boundaries reacts partly with alumina from the cells to form $\mathrm{NiAl}_{2} \mathrm{O}_{4}$, which would provide better protection.
\end{abstract}

\section{Introduction}

I N METAL-TOUGHENED ceramics, ductile ligaments bridge crack surfaces, and the plastic work associated with stretching these ligaments during fracture results in enhanced toughness. ${ }^{1-9}$ The reinforcing metal phase can exist as discrete inclusions ${ }^{1.2}$ or can have connectivity in all three directions. ${ }^{3,4,6}$ In both cases, the metal reinforcements increase the resistance to propagation of cracks (increase fracture toughness) but still result in brittle, catastrophic failure in strength tests. When the metal phase is present as thick $(>100-\mu \mathrm{m})$ layers with planar continuity as in the alumina/ $\mathrm{Ni}$ laminates of Chen and Mecholsky, ${ }^{9}$ the composite shows noncatastrophic fracture behavior. The thick sheets of Ni bridge the crack surfaces in flexure tests and keep the specimens intact.

The "fibrous monolith" approach" ${ }^{10.11}$ is a new process for creating ceramic microstructures with metallic/ceramic interphases. The fibrous monolith microstructure consists of highaspect-ratio polycrystalline cells of a primary phase separated by thin cell boundaries of a second phase. There are no reinforcing fibers. The cells are flattened polycrystalline regions (e.g., alumina) that are remnants of powder-loaded polymer "green" fibers. A coating applied on the green fiber forms the cell boundary (e.g., nickel), which can be any thermodynamically compatible second phase designed to enhance the fracture resistance of the material. When the cell boundary has low

N. S. Jacobson-contributing editor

Manuscript No. 194283. Received August 23, 1993; approved January 31, 1994

Supported by the Advanced Research Projects Agency and the Office of Naval Research under Contract No. N00014-91-J-1999.

${ }^{*}$ Member, American Ceramic Society.

${ }^{+}$Now with Battelle Pacific Northwest Laboratory, Richland, WA.

${ }^{\ddagger}$ Now with Oak Ridge National Laboratory, Oak Ridge, TN shear strength (graphite or BN), the material fails noncatastrophically in flexure. ${ }^{11-13}$ The fibrous monolith is flaw-tolerant and notch-insensitive.

The fabrication of fibrous monoliths in the alumina/ $\mathrm{Ni}$ system has been described earlier. " Two features of this ceramicmetal microstructure are unique. The $\mathrm{Ni}$ cell boundary phase is thin and occupies only about 3 to 8 vol\% of the material. This is quite small compared to alumina/ $\mathrm{Ni}$ laminates, ${ }^{9}$ which contained about 30 to $45 \mathrm{vol} \%$. The $\mathrm{Ni}$ cell boundary phase also isolates each of the long alumina cells and has connectivity in all three directions. The objective in this study was to determine the effect of this microstructural layout on the fracture behavior of the alumina/nickel system. Mechanical properties of an alumina/Ni fibrous monolith with aligned cells were evaluated. The experiments addressed the following questions: (1) How does the material fracture in a "standard" flexure test? (2) What is the effect of a stress intensifier such as a notch in a flexure specimen? (3) Is the strength significantly reduced by point contact damage? (4) Since tough ceramics with high specific modulus are candidate materials for replacing Ni-base superalloys in gas turbine engine applications, do alumina/Ni fibrous monoliths have potential for use at high temperature?

\section{Experimental Procedure}

Suspensions of alumina powder (RC-HP DBM, Malakoff Industries, Malakoff, TX) in an ethyl methacrylate (EMA)/ methyl ethyl ketone (MEK) solution (B7/MEK Acryloid, 30 wt $\%$ solution, Rohm and Haas, Philadelphia, PA) were ballmilled. A phosphate ester (P5-21A, Witco, New York) was used as the dispersant. The milled suspensions were then concentrated by evaporation of the MEK to a pastelike consistency. The concentrated "dopes" were extruded to form soft "green fibers" by dry-spinning into a hot-air column maintained at $100^{\circ} \mathrm{C}$. Yttria-stabilized zirconia (TZ-3Y, Tosoh USA, Bridgewater, $\mathrm{NJ}$ ) was used as a grain growth inhibitor for the alumina. The volume ratio of $\mathrm{Al}_{2} \mathrm{O}_{3}$ to $\mathrm{ZrO}_{2}$ was $96: 4$ (weight ratio of $94: 6$ ). The volume ratio of ceramic powder to ethyl methacrylate polymer in the dry fiber was 60:40. Green fibers typically had a "dog-bone" cross section, "with an area-equivalent circular diameter of $100-150 \mu \mathrm{m}$. More details on dope preparation and spinning are given elsewhere. ${ }^{11}$

The green fibers were run through a coating slurry of $\mathrm{NiO}$ (N-69, Fisher Scientific, Fairlawn, N.J) immediately after extrusion. The suspension medium for the coating slurry was a mixture of iso(propyl alcohol) and deionized water. Menhaden fish oil (Z-3, Kellox Div., Textron, Buffalo, NY) was used as a dispersant, with poly(vinyl alcohol) (KH175, Nippon Gohsei, Tokyo, Japan) as the binder and poly(ethylene glycol) (Carbowax PEG 4000, Fisher) as plasticizer. (Coating thickness was adjusted by controlling slurry composition and properties to provide a final nickel content of $\sim 8 \mathrm{vol} \%$ in the material. A single billet was made with a thinner coating, adjusted for about 3 vol\% final nickel content.) The coated fibers with the thick $\mathrm{NiO}$ coating (corresponding to 8 vol\% Ni) were trimmed to $51-\mathrm{mm}$ lengths and loaded in a $52 \mathrm{~mm} \times 26 \mathrm{~mm}$ graphite die with the 
fibers aligned parallel to the long die wall. The fibers with the thinner coating were trimmed to $41-\mathrm{mm}$ lengths and loaded in a $32 \times 42 \mathrm{~mm}$ die. The different sizes reflect availability of dies in different stages of this study.

The green fibers were pressed at $80^{\circ} \mathrm{C}$ using 5-MPa pressure. This softens the polymer and consolidates the fibers into a dense monolithic billet with 40 vol\% polymer. After removal of the polymer binder between $200^{\circ}$ and $600^{\circ} \mathrm{C}$ in an actively pumped vacuum, the billets were hot-pressed at $1400^{\circ} \mathrm{C}$ in nitrogen for $1 \mathrm{~h}$ using 25-MPa ram pressure. During hot-pressing, $\mathrm{NiO}$ is reduced to $\mathrm{Ni}$ cell boundaries in the material. Hot-pressed billets varied from 3.5 to $5.5 \mathrm{~mm}$ in thickness.

Billets with 8 vol\% nickel were machined either into bar specimens 3 to $4.5 \mathrm{~mm}$ thick, $4 \mathrm{~mm}$ wide, and $48 \mathrm{~mm}$ long, or into tall beams $4.5 \mathrm{~mm}$ high, $2.3 \mathrm{~mm}$ wide, and $48 \mathrm{~mm}$ long. All specimens were machined with a 1000 -grit resin-bonded diamond wheel. with the grinding direction parallel to the length of the specimen. The bars for flexure tests were also chamfered. The tension side was normal to the pressing direction. In some cases, the side surfaces of samples were polished prior to testing. Flexural strength was measured on two bars, using a fully articulated four-point bend fixture with a $20-\mathrm{mm}$ inner span and a $40-\mathrm{mm}$ outer span at a crosshead speed of $0.05 \mathrm{~mm} / \mathrm{min}$. A single bar specimen was polished, indented with a Vickers diamond (Zwick Indenter, Zwick of America, E. Windsor, CT) using a $10-\mathrm{kg}$ load, and tested to failure. Stress values were calculated from elastic beam equations.

The tall beams were notched to a depth of about $1.8 \mathrm{~mm}$ using a $250-\mu \mathrm{m}$-wide diamond wafering blade. Notch depth/ specimen height was about 0.4 . Actual notch radii were 140 $\mu \mathrm{m}$. The notched beams were tested in the same $20 / 40-\mathrm{mm}$ four-point fixture used for the bend bars. The equation of Brown and Srawley ${ }^{14}$ was used to estimate fracture toughness from the maximum load.

The smaller billet with 3 vol\% nickel was machined into bars $2 \mathrm{~mm} \times 2 \mathrm{~mm} \times 42 \mathrm{~mm}$ in size, and into tall beams $2 \mathrm{~mm}$ wide, $3 \mathrm{~mm}$ high, and $42 \mathrm{~mm}$ long. The tall beams were notched with the $250-\mu \mathrm{m}$-wide diamond blade to a depth of $1.15 \mathrm{~mm}$. The bars were tested in a four-point bend fixture with a $15-\mathrm{mm}$ inner span and a 30-mm outer span.

Density of bars was measured by the Archimedes method. Young's modulus was measured on bar specimens with $8 \mathrm{vol} \%$ nickel by the flexural resonance method, ${ }^{15.16}$ using GrindoSonic (J. W. Lemmens, St. Louis, MO) equipment. Damage and cracking from Vickers indentations (Zwick) were studied on the side surface of a bar with 8 vol\% nickel. An indentation load of $10 \mathrm{~kg}$ (about $100 \mathrm{~N}$ ) was used with 30-s residence time.

Machined bar and notched beam specimens containing 8 vol\% nickel were also heat-treated in air al $1200^{\circ} \mathrm{C}$ for $10 \mathrm{~h}$. Heating and cooling rates were $15^{\circ} \mathrm{C} / \mathrm{min}$ between $500^{\circ} \mathrm{C}$ and the heat-treatment temperature. The heat-treated specimens were tested in flexure at room temperature.

Fractured specimens were inspected using optical and scanning electron microscopy. Some specimens were inspected with an optical microscope during the flexure test. Cross sections after test were polished and then studied by optical microscopy.

\section{Results and Discussion}

\section{(1) Microstructure, Elastic Modulus, and Indentation}

\section{Behavior}

The microstructure of alumina/Ni fibrous monoliths with aligned fibers is shown in Fig. 1. The alumina cells are flattened by the forming process, with thickness (Fig. 1(C)) ranging from 60 to $100 \mu \mathrm{m}$, and width (Fig. 1(A)) from 100 to $160 \mu \mathrm{m}$. Only short cell lengths up to a few millimeters are visible in the micrographs, but individual cells could actually have continuity and extend for long distances up to a maximum of $5.2 \mathrm{~cm}$. The $\mathrm{Ni}$ cell boundary thickness varies from 1 to $15 \mu \mathrm{m}$.

The density of the alumina( + zirconia)/nickel fibrous monolith with the thicker cell boundary was $4.45 \mathrm{~g} / \mathrm{cm}^{3}$. X-ray diffraction of the outside surface of the billet showed that the only phases present were alumina, nickel, and tetragonal zirconia. The alumina cells were seen to be pore-free by scanning electron microscopy. About 0.5 vol\% porosity in the material was present at the cell boundaries (see Fig. 1(B)). From the theoretical density of alumina( $+4 \mathrm{vol} \%$ zirconia) and nickel metal, the volume fraction of nickel is estimated to be about 0.08 . The alumina/nickel billet with less nickel had a density of 4.13 $\mathrm{g} / \mathrm{cm}^{3}$, which is equivalent to alumina with about 3 vol\% nickel.

From optical microscopy of billet cross sections containing 8 vol\% nickel, the color of the cells was found to vary from blue in the central section (about 2.5-mm thickness), to gray in the outer layers (1-mm thickness), which were near the graphite die walls during hot-pressing. The starting $\mathrm{NiO}$ powder was a moderately dark green, and $\mathrm{NiAl}_{2} \mathrm{O}_{4}$ is known to be bluc in color. $\mathrm{X}$-ray diffraction indicated that the central section was predominantly alumina and nickel, with a small $(<5 \%)$ amount of $\mathrm{NiAl}_{2} \mathrm{O}_{4}$ and trace $\mathrm{NiO}$. It appears that the blue coloration is due to trace amounts of $\mathrm{NiAl}_{2} \mathrm{O}_{4}$ formed from reaction of the alumina with some $\mathrm{NiO}$ that was not reduced in the central section of the billet. ${ }^{\S}$ An exact determination of the spatial distribution of the $\mathrm{NiAl}_{2} \mathrm{O}_{4}$ phase awaits detailed inspection of the $\mathrm{Ni} / \mathrm{alu}$ mina interface by transmission electron microscopy.

The Young's modulus values of three bar specimens of the alumina $/ 8$ vol\% $\mathrm{Ni}$ fibrous monolith were 335,343 , and 347 $\mathrm{GPa}$. Young's modulus of dense polycrystalline alumina (density $=3.95-3.99 \mathrm{~g} / \mathrm{cm}^{3}$ ) is in the range $380-400 \mathrm{GPa}$. Nickel metal with density of $8.9 \mathrm{~g} / \mathrm{cm}^{3}$ has a modulus of 205 GPa. ${ }^{17}$ The low density and high modulus of the alumina/nickel fibrous monolith make this material attractive for applications requiring high specific stiffness, especially in comparison with nickel alloys.

Surface damage from a Vickers indentation on the 8 vol\% Ni-fibrous monolith is shown in Fig. 2. Indents in the load range 10-100 $\mathrm{N}$ are comparable in size to the cell width, so crack patterns typical of homogeneous brittle materials do not form. The nickel cell boundaries prevent the formation of long cracks. Interfacial cracks that form along the cell boundaries are seen to propagate into the cells at about $45^{\circ}$ to the cell boundaries some distance from the indent. The radial cracks in the direction normal to the cell axes are generally confined to one cell width. Deformation and uplift of the Ni cell boundaries at the top and bottom indent corners are also observed. Since cells are only $50-150 \mu \mathrm{m}$ deep, the lateral cracks from indentation also cause some parts of cells to spall.

\section{(2) Flexural Strength Behavior}

The strength behavior of the alumina $/ 8$ vol\% Ni fibrous monolith is shown in Fig. 3. Maximum stress on the tension side is plotted as a function of crosshead displacement for a 3-mm-thick bar specimen. The applied stress value is meaningful only up to the first load drop, beyond which elastic beam equations are not valid. Peak stress is $268 \mathrm{MPa}$, and the material displays noncatastrophic fracture behavior, retaining about $40 \%$ of the maximum load after the first fracture event. Failure initiates on the lension side between the inner loading points, with the crack propagating past the neutral axis. The side surface of the specimen on the tension side of the neutral axis is shown in Fig. 4. Both crack deflection/branching along the cell boundaries and deformation of $\mathrm{Ni}$ that had bridged across the fracture surfaces during the test are evident. Beyond the neutral axis near the compression side, significant crack branching occurs in the axial direction. This, combined with some bridging ligaments of $\mathrm{Ni}$, provides load-bearing capability in the cracked specimen.

The amount of nickel at the cell boundary affects the fracture behavior. Two bars from the billet containing 3 vol\% nickel were tested. Both samples failed in a brittle fashion, breaking in two. The strength values were 287 and $375 \mathrm{MPa}$. These results

${ }^{8}$ Preliminary experiments using $\mathrm{NiO}$ plus small amounts of graphite as the fiber coating indicate that complete reduction to $\mathrm{Ni}$ in thick sections can be achieved. 


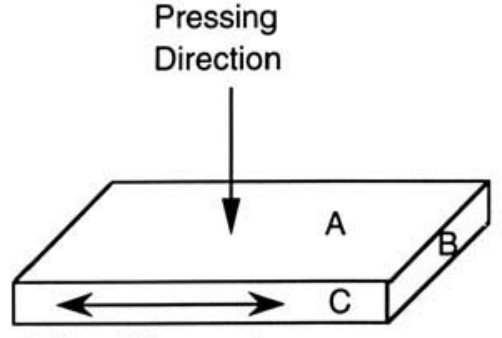

Fiber Alignment

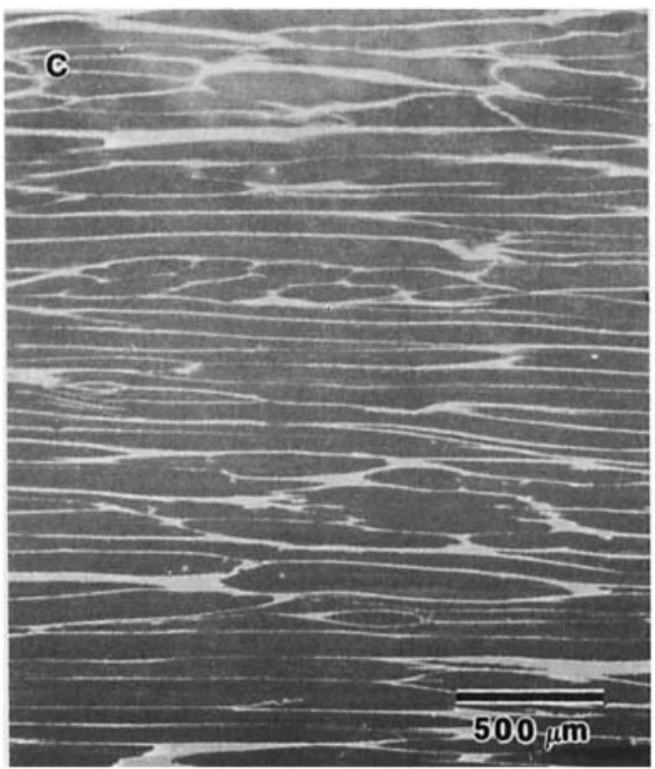

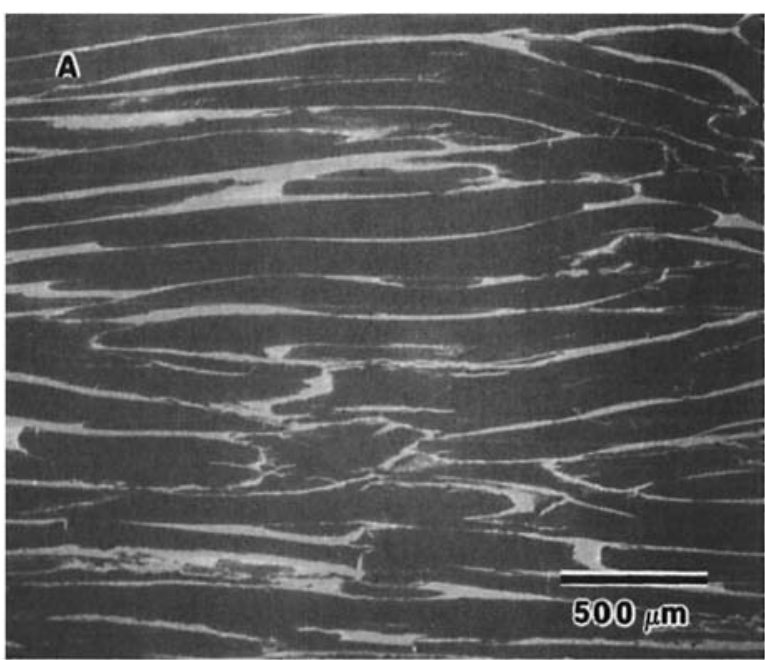

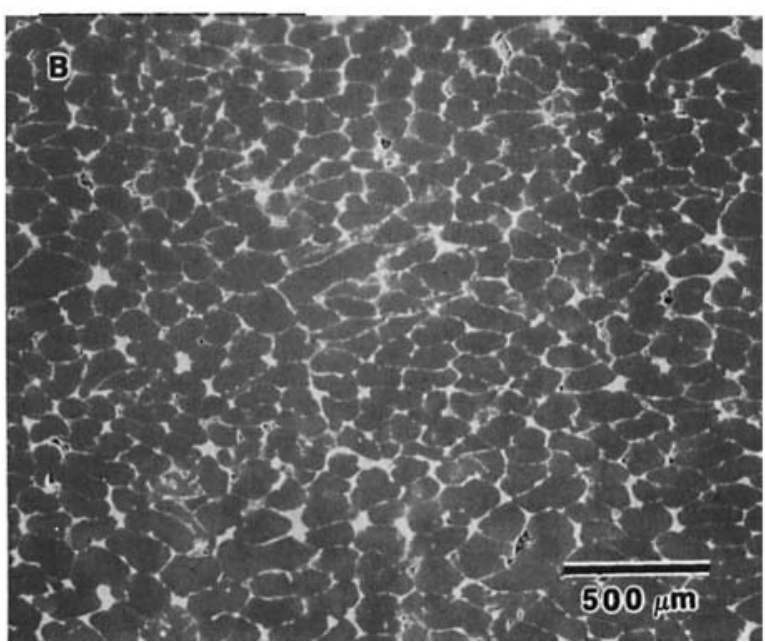

Fig. 1. Microstructure of alumina/nickel fibrous monolith prepared with aligned green fibers. The nickel cell boundaries appear bright in the SEM micrographs.

indicate that a minimum amount of nickel is required at the cell boundaries to prevent brittle fracture in flexure bars.

A concern in uniaxial structures of dissimilar materials is the possibility of interfacial cracking preceding other fracture events. In thick bend specimens, the applied shear stresses between the inner and outer loading points are high and can cause delamination cracking when interlaminar shear strengths are low. ${ }^{12.13}$ For a thick $(4.5-\mathrm{mm})$ bar of the alumina $/ 8$ vol $\% \mathrm{Ni}$, strength was $246 \mathrm{MPa}$ and the sample failed in a noncatastrophic manner. Fracture initiated from the tension side, and not by midplane shear delamination. For an applied tensile stress of $246 \mathrm{MPa}$, the maximum applied shear stress is $28 \mathrm{MPa}$ for this specimen/fixture configuration. ${ }^{12}$ The absence of shear cracking in this thick sample indicated that the $\mathrm{Ni}$ /alumina interfaces had reasonably high shear strengths and that failure by delamination was not a critical issue.

The load-deflection behavior for a single-edge-notched beam (SENB) if alumina/8 vol\% Ni is shown in Fig. 5 . Fracture is noncatastrophic. The load continues to rise after fracture has begun, followed by a gradual decrease in load. The SEM micrograph in Fig. 6(A) shows a primary crack has propagated straight ahead from the tip of the notch. The primary crack was observed at the first sign of nonlinearity in the load-deflection curve. With further crosshead displacement, a secondary crack, which ran almost parallel to the primary crack, was initiated at the tip of the notch. As is evident from Fig. 6(A), there is some tendency for crack deflection along the cell boundaries, and also thick ligaments of $\mathrm{Ni}$ bridging the crack surfaces. In Fig. 6(B), the fractured surface of a section of a notched beam pulled apart after the test shows ductile ridges of $\mathrm{Ni}$, as well as plastic rupture of a long nickel section by void growth, both typical of metal fracture. $5,6,9$

The $K_{\mathrm{I} c}$ calculated from the maximum load was $5.8 \mathrm{MPa}$. $\mathrm{m}^{1 / 2}$. This $K_{\mathrm{I}}$, value is slightly higher than typical values for alumina, but the toughness from notched beams is also affected by experimental parameters such as notching techniques and notch width. ${ }^{18.19}$ The important observation here is that fracture is not catastrophic from a stress concentration in a flexure specimen of the fibrous monolith.

The load-deflection behavior for a SENB specimen of the alumina $/ 3$ vol\% Ni fibrous monolith is shown in Fig. 7. Here, the first fracture event immediately results in a load decrease. Once the crack has initiated, the thinner nickel cell boundary network results in less load-bearing capability. But the sample with only 3 vol\% $\mathrm{Ni}$ continues to sustain load with further crosshead displacement and does not break in two. The mode I fracture toughness calculated from the peak load was 6.2 $\mathrm{MPa} \cdot \mathrm{m}^{1 / 2}$.

A noteworthy feature in the flexural response of the alumina/ nickel fibrous monolith is that noncatastrophic fracture behavior is observed in spite of infrequent occurrence of plastically stretched ligaments of nickel. The ligaments are generally thin (1 to $15 \mu \mathrm{m}$ ), and only the thicker metal elements appear to bridge crack surfaces (Fig. 6(A)). The thickness effect is consistent with other investigations ${ }^{5,9}$ on metal-toughened ceramics which have shown that the toughening contribution (i.e., work of stretching) from the metal increases with ligament size. The $\mathrm{Ni}$ cell boundaries are thin, but the nickel is present in the form 


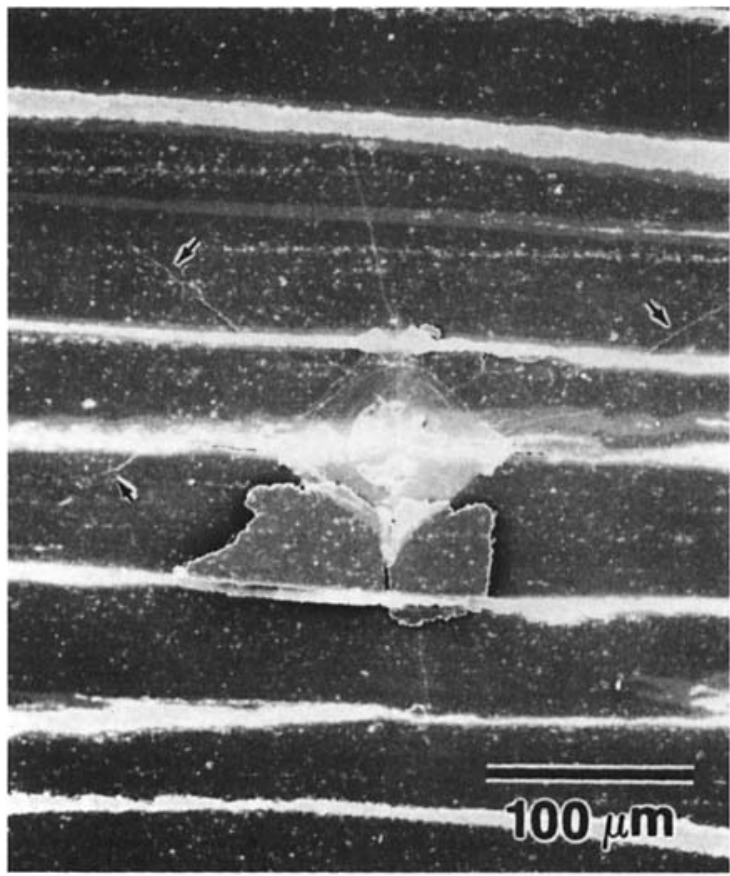

Fig. 2. SEM micrograph showing indentation fracture in an alumina/ nickel fibrous monolith (load $=100 \mathrm{~N}$ ). Indented surface was parallel to the hot-pressing direction. Arrows indicate cracks propagating into cells from the cell boundaries.

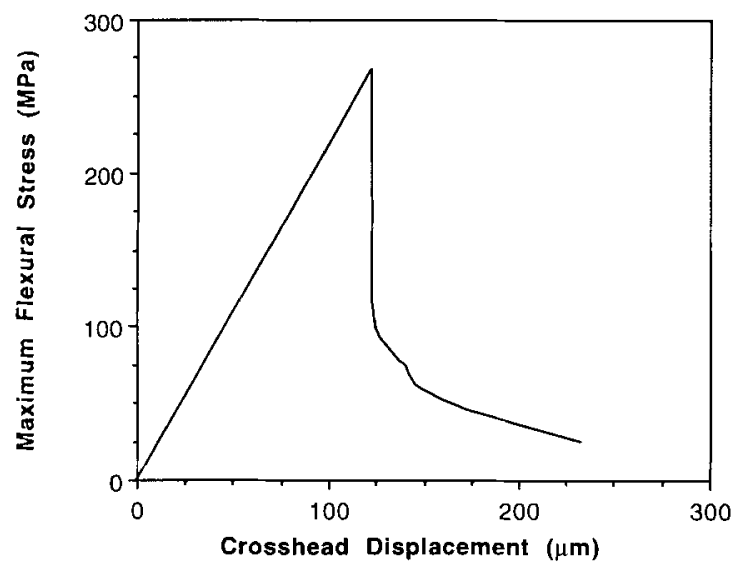

Fig. 3. Flexural strength behavior of aligned-fiber alumina $/ 8$ vol\% nickel. Thickness of flexure specimen was $3 \mathrm{~mm}$.

of interconnected thin-walled tubes which are filled with dense, polycrystalline alumina. It is this contiguous network form of nickel, at only $8 \mathrm{vol} \%$ of the composite structure, that imparts toughness to the material and prevents brittle fracture in strength specimens. In SENB specimens, as little as $3 \mathrm{vol} \%$ nickel in the form of a cell boundary network is enough to prevent brittle fracture.

The effect of indentation on strength behavior of alumina/ 8 vol\% $\mathrm{Ni}$ is shown in Fig. 8(A). Fracture is not catastrophic, and strength is essentially unchanged ( $251 \mathrm{MPa}$ ). Indentation does not result in strength-degrading flaws (Section III(1), Fig. 2). The SEM micrograph of the tension side of this specimen shown in Fig. 8(B) confirms that failure does not initiate from the indent.

\section{(3) Effect of Oxidation}

The effect of heat treatment at $1200^{\circ} \mathrm{C}$ on the room-temperature flexural strength behavior of the alumina $/ 8 \mathrm{vol} \%$ nickel fibrous monolith is compared with an untreated sample in

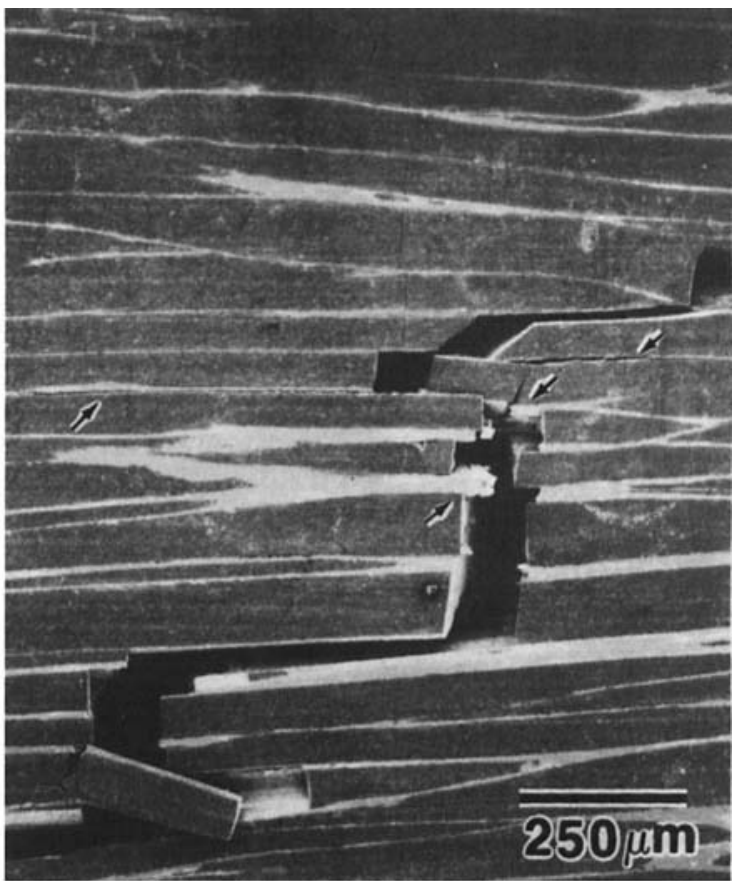

Fig. 4. SEM micrograph showing side surface of alumina/8 vol\% nickel bend specimen after test. Arrows indicate cracking along cell boundaries and nickel ligaments that had bridged the crack surfaces.

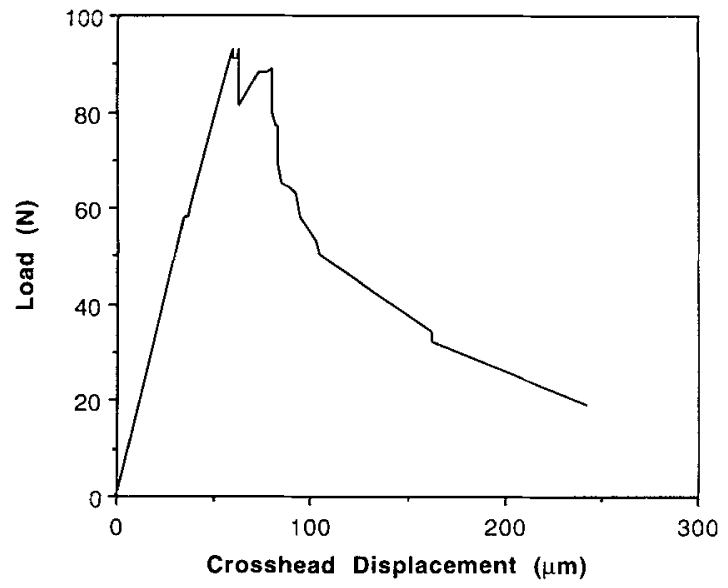

Fig. 5. Load-deflection behavior for a notched beam of the alumina/ $8 \mathrm{vol} \%$ nickel fibrous monolith in flexure.

Fig. 9. Fracture is noncatastrophic, and the apparent strength is $216 \mathrm{MPa}$. The effect of heat treatment on the load-deflection behavior of a notched beam is shown in Fig. 10. The specimen does not fail in a brittle manner. Significant load-bearing ability is recorded after a crack has propagated from the notch. For the heat-treated notched beam, the $K_{\mathrm{I} c}$ calculated from the load, notch depth, and specimen dimensions is $5.9 \mathrm{MPa} \cdot \mathrm{m}^{1 / 2}$, which is almost the same as for the untreated material.

The side surface of the flexure bar after the test is shown in Fig. 11. The optical micrograph in Fig. 11(A) shows the surface of the bar has turned bluish-green on heat treatment. The bar remains intact after significant bending during the test. The SEM micrograph in Fig. 11(B) illustrates the fracture path. The primary crack has deflected along a cell boundary in the midsection of the bar, leading to additional crack branching both on the left and right of the main crack.

$\mathrm{X}$-ray diffraction of the side surface of the heat-treated bar indicates that the major phase is alumina, with $\mathrm{NiO}, \mathrm{NiAl}_{2} \mathrm{O}_{4}$, $\mathrm{Ni}$, and tetragonal $\mathrm{ZrO}_{2}$ as the minor phases. Optical microscope examination of a polished section of a specimen oxidized 

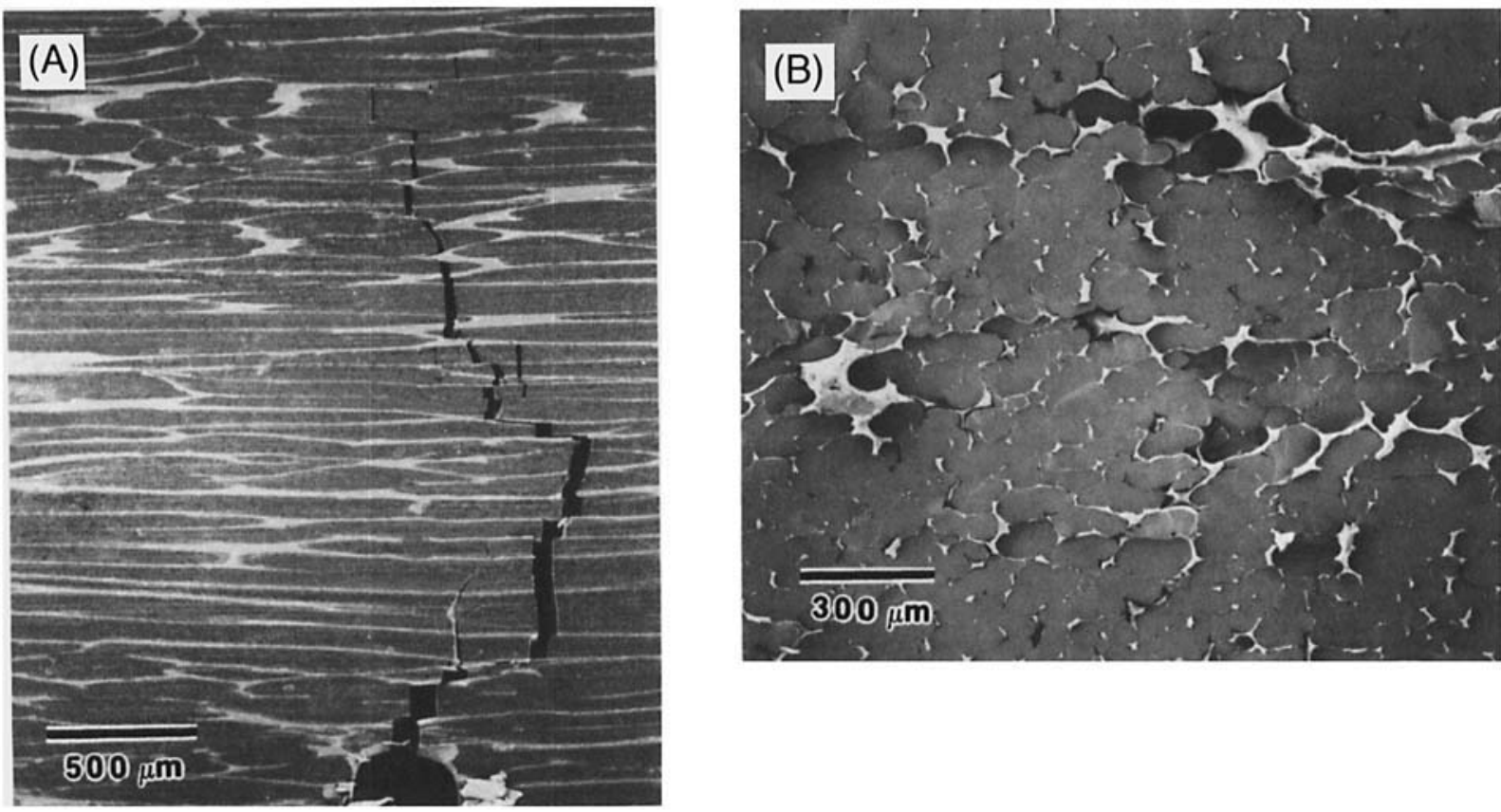

Fig. 6. SEM micrographs showing (A) side surface of alumina/8 vol\% nickel notched beam after test and (B) fracture surface of a notched beam pulled apart after the test.

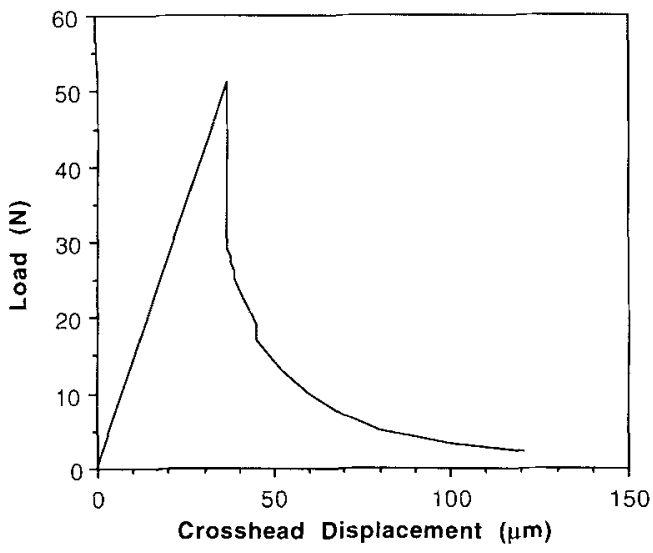

Fig. 7. Load-deflection behavior for a notched beam of the alumina/ 3 vol\% nickel fibrous monolith in flexure.

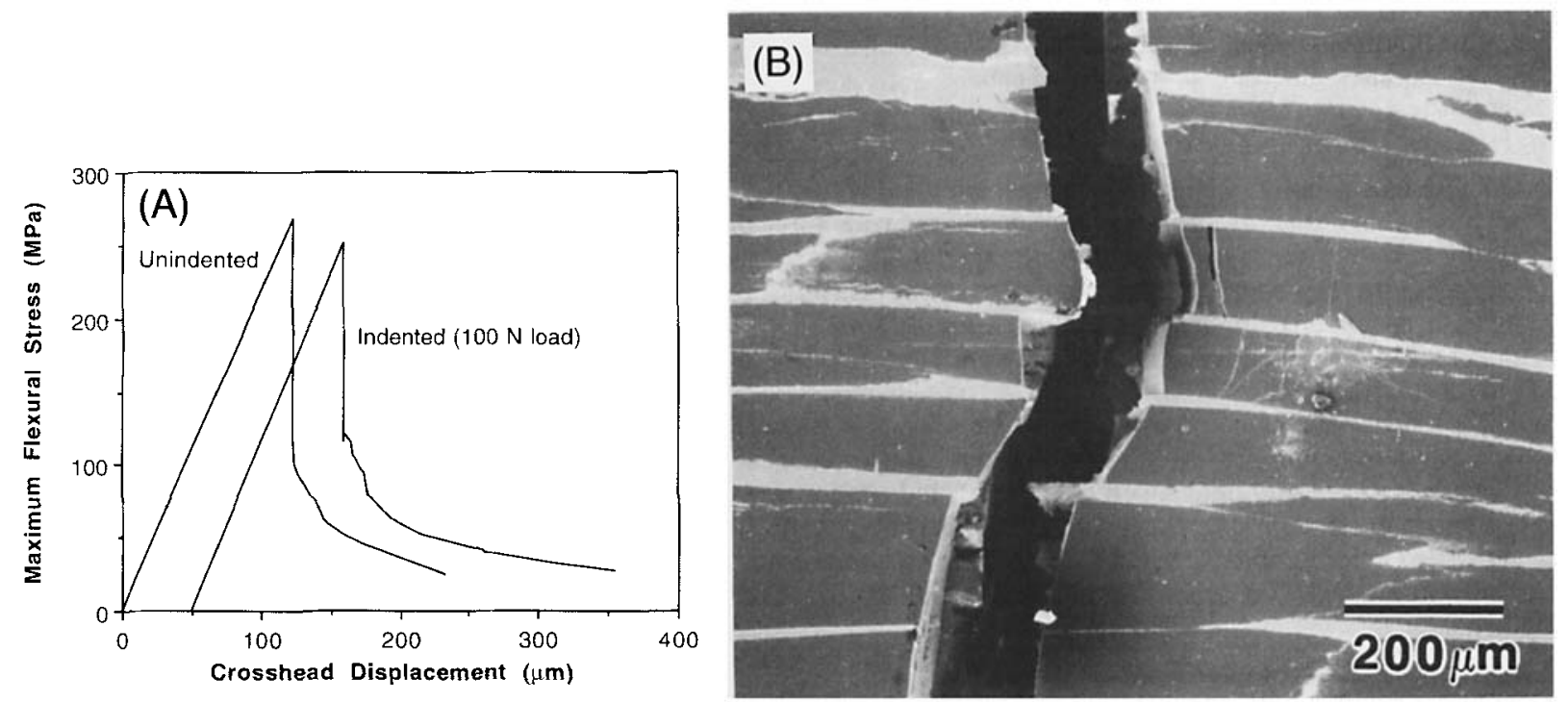

$10 \mathrm{~h}$ at $1200^{\circ} \mathrm{C}$ shows that the cell boundaries on the surface have turned bluish-green. The color extends to a depth of 50 to $100 \mu \mathrm{m}$, or about a half-cell deep. The green NiO color predominates in the deeper portion of the colored region, with blue $\mathrm{NiAl}_{2} \mathrm{O}_{4}$ present nearer the surface. This suggests that the nickel aluminate forms by reaction of the $\mathrm{NiO}$ with the alumina in the adjacent cells. Since the bulk of the alumina/Ni material is unaffected by the $1200^{\circ} \mathrm{C}(10-\mathrm{h})$ heat treatment, the fracture behavior is unchanged.

The depth of the oxidized cell boundary network correlates well with a NiO scale thickness of $60 \mu \mathrm{m}$ expected after a similar heat treatment on pure nickel, assuming a parabolic rate constant of $10^{-9} \mathrm{~g}^{2} /\left(\mathrm{cm}^{4} \cdot \mathrm{s}\right)$ for Ni oxidation. ${ }^{20.21}$ The first oxidation product, semiconducting $\mathrm{NiO}$, would be relatively unprotective. However, reaction with the alumina cells would seal the cell boundaries with nickel aluminate, which has a lower electrical conductivity. This should result in better oxidation resistance. In nickel-base supperalloys, the formation of aluminumcontaining oxides is very desirable for oxidation resistance. ${ }^{21}$

Fig. 8. (A) Flexural strength behavior of aligned-fiber alumina/nickel showing effect of indentation. (B) SEM micrograph of the tension side of the indented bar specimen. Failure does not initiate at indent. 


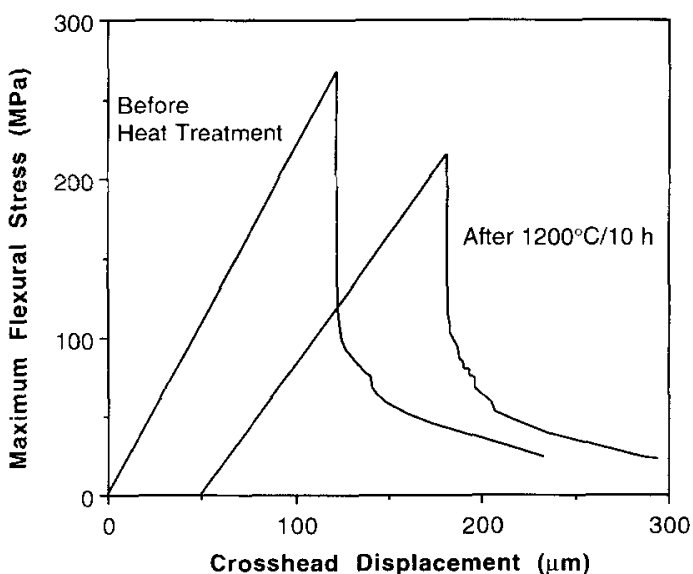

Fig. 9. Room-temperature flexural strength behavior of alumina/ 8 vol\% nickel fibrous monolith showing effect of 10 -h heat treatment at $1200^{\circ} \mathrm{C}$

The oxidation resistance of the fibrous monolith can possibly be improved by using well-established methods for protecting nickel alloys. ${ }^{21.22}$ For example, using a Ni-Cr alloy with 5-20 wt $\% \mathrm{Cr}$, or simply using alumina-formers such as MCrAlY $(\mathrm{M}=\mathrm{Ni}, \mathrm{Co})$ overlay materials as the cell boundary phase, may significantly improve the resistance of the fibrous monolith to high-temperature degradation.

\section{(4) Concluding Remarks}

Nickel is the first example of a ductile phase incorporated into a fibrous monolith structure as the cell boundary by reduction of the oxide during firing. Other metals (e.g., Fe) could also be introduced as the cell boundary phase by this method, provided the thermodynamics favor reduction of the corresponding metal oxides in carbon-rich or reducing environments. Alternatively, a slurry of a fine metal powder may be used to coat the green ceramic fiber.

The alumina/nickel fibrous monolith also has potential because of its low cost. The alumina powder is inexpensive, and the most expensive $\mathrm{NiO}$ powder is used only in small quantities. In this study, hot-pressing was used for convenience, but the material can be densified by sintering. Alumina/nickel particulate composites ${ }^{2}$ and laminates" have been densified by pressureless sintering. Other alumina-based fibrous monoliths have also been sintered to full density." Sintered alumina/nickel

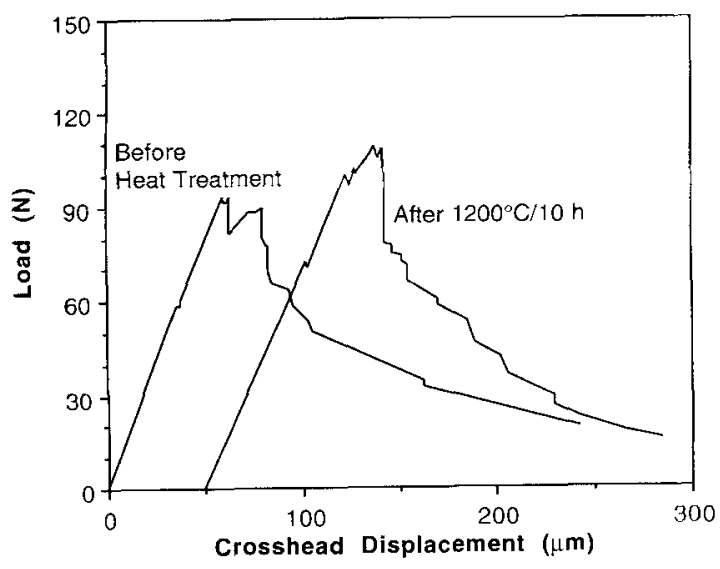

Fig. 10. Room-temperature load-deflection behavior of alumina/8 vol\% nickel notched beam showing effect of 10 -h heat tretment at $1200^{\circ} \mathrm{C}$.

fibrous monolith could be a cost-effective high-temperature engineering material.

\section{Conclusions}

Fibrous monolithic ceramics can be fabricated with polycrystalline alumina cells with thin ribbons of nickel as cell boundaries. Uniaxially aligned alumina/ $\mathrm{Ni}$ fibrous monoths with 8 vol\% $\mathrm{Ni}$ have flexural strengths in the range of $246-375 \mathrm{MPa}$. Fracture is noncatastrophic, with retained loads up to $40 \%$ of the peak load. Fracture occurs by tensile cracking. Bridging ligaments of $\mathrm{Ni}$, crack deflection along alumina/ $\mathrm{Ni}$ cell boundaries, and crack branching in the axial directions can be observed. Strength is not significantly degraded by $100-\mathrm{N}$ Vickers indentations. Uniaxially aligned alumina/ $\mathrm{Ni}$ fibrous monothis with $3 \mathrm{vol} \% \mathrm{Ni}$ have brittle fracture in flexure. The 3 vol\% $\mathrm{Ni}$ and 8 vol\% $\mathrm{Ni}$ specimens display noncatastrophic fracture in the single-edge-notched beam test. Failure begins at a load corresponding to a $K_{\mathrm{I} c}=5.9 \mathrm{MPa} \cdot \mathrm{m}^{1 / 2}$, but load continues to rise after fracture initiates. The room-temperature flexural behavior is not significantly changed by 10 -h oxidation in air at $1200^{\circ} \mathrm{C}$, suggesting useful oxidation resistance. The $\mathrm{NiO}$ cell boundary oxidation product reacts with alumina to form nickel aluminate spinel.

Acknowledgment: Lynne Svedberg provided valuable assistance in fiber spinning.
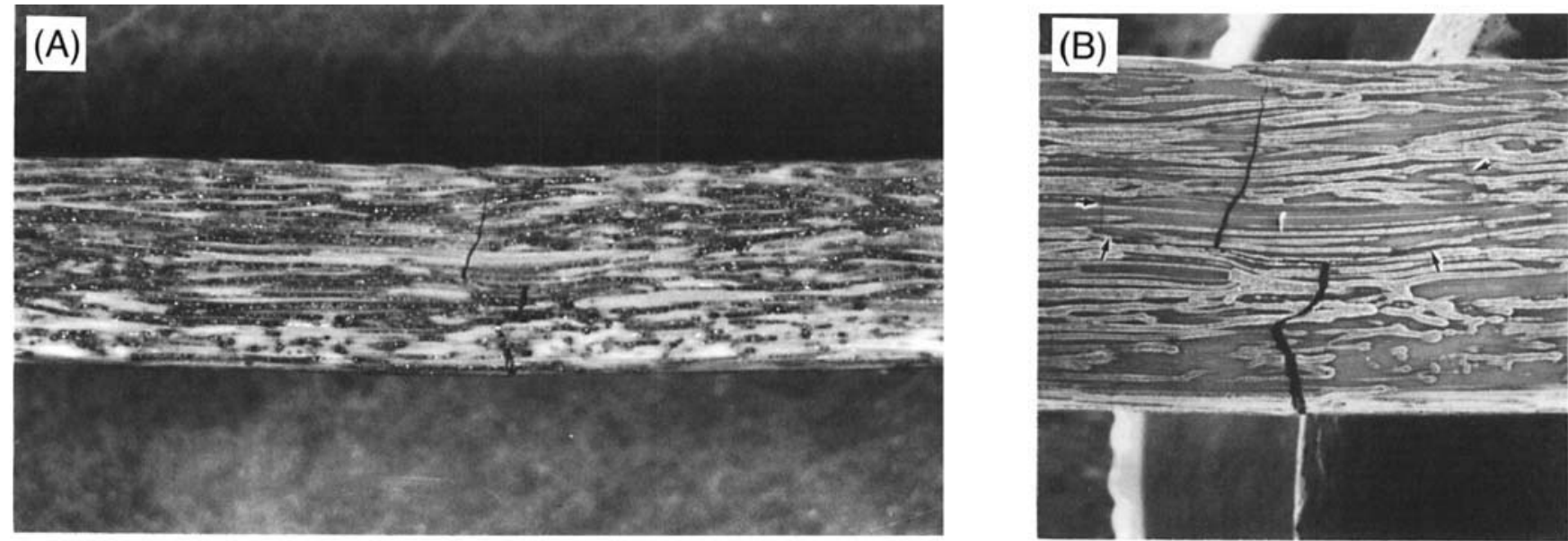

Fig. 11. (A) Optical micrograph showing side surface of heat-treated bar after test. (B) Higher magnification SEM micrograph of the crack profile on the side surface. Arrows indicate cracks branching off the main crack. Magnification in micrographs can be estimated from the 3-mm thickness of the test specimen. 


\section{References}

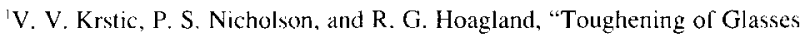
by Metallic Particles," J. Am. Ceram. Soc., 64 [9] 499-504 (1981).

${ }^{2}$ W. H, Tuan and R. J. Brook, "The Toughening of Alumina with Nickel Inclusions," J. Eur. Ceram. Sox. 6, 31-37 (1990).

M. S. Newkirk, A. W. Urquhart, H. R. Zwicker, and E. Breval, "Formation of Lanxide ${ }^{\text {TM }}$ Ceramic Composite Materials,"J. Mater. Res., 1 ll] 81-89 (1986).

${ }^{4}$ M. K. Aghajanian, N. H. McMillan, C. R. Kennedy, S. J. Luszcr, and R. Roy, "Properties and Microstructure of Lanxide $\mathrm{Al}_{2} \mathrm{O}_{3}-\mathrm{Al}$ Ceramic Composite Materials." J. Mater. Sci., 24, 658-70 (1989)

"M. K. Ashby, F. J. Blunt, and M. Bannister, "Flow Characteristics of Highly Constrained Metal Wires," Acta Metall., 37 [7] 1847-57 (1989).

"B. D. Flinn, M. Ruhle, and A. G. Evans, "Toughening in Composites of $\mathrm{Al}_{2} \mathrm{O}_{3}$ Reinforced with Al," Acta Metall., 37 [11] 3001-3006 (1989).

B. D. Flinn, C. S. Lo. F. W. Zok, and A. G. Evans, "Fracture Resistance Characteristics of a Metal-Toughened Ceramic," J. Am. Ceram. Soc', 76 [2] 369-75 (1993).

${ }^{x}$ M. Yasrebi, G. H. Kim, K. E. Gunnison, D. L. Milius, M. Sarikaya. and I. A. Aksay, "Biomimetic Processing of Ceramics and Ceramic-Metal Composites," Mater. Res. Soc. Symp. Pro., 180, 625-35 (1990).

"Z. Chen and J. J. Mecholsky, Jr., "Toughening by Metallic Lamina in Nickel/ Alumina Composites," J. Am. Ceram. Soc., 76 [5] 1258-64 (1993).

${ }^{10} \mathrm{~W}$. S. Coblenz, "Fibrous Monolithic Ceramic and Method for Production," U.S. Pat. No. 4772 524, September 20, 1988.

${ }^{\prime S}$ S. Baskaran, S. D. Nunn, D. Popovic, and J. W. Halloran. "Fibrous Monolithic Ceramics: I, Fabrication, Microstructure, and Indentation Behavior," J. Am. Ceram. Soc., 76 [9] 2209-16 (1993).
${ }^{12}$ S. Baskaran and J. W. Halloran, "Fibrous Monolithic Ceramics: II, Flexural Strength and Fracture Behavior of the Silicon Carbide Graphite System," J. Am. Ceram. Soc., 76 [9] 2217-24 (1993).

${ }^{13}$ S. Baskaran and J. W. Halloran, "Fibrous Monolithic Ceramics: III, Mechanieal Properties and Oxidation Behavior of the Silicon Carbide/Boron Nitride System," J. Am. Ceram. Sor., 77 [5] 1249--55 1994.

${ }^{14}$ W. F. Brown, Jr, and 3. E. Srawley, "Plane Strain Crack Toughness Testing of High Strength Metallic Materials," STP 410, 13-14. American Society for Testing and Materials, Philadelphia, PA, 1966.

${ }^{15}$ E. Schreiber, O. L. Anderson, and N. Soga, Elastic Constants and Their Measuement; Ch. 4. McGraw-Hill, New York, 1973.

"S. Spinner and W. E. Tefft, "A Method for Determining Mechanical Resonance Frequencies and for Calculating Elastic Moduli from these Frequencies," Proc. Am. Soc. Test. Mater., 61, 1229 (1961).

${ }^{7}$ R. C. Weast (Ed.), CRC Handhook of Chemistry and Physics, 64th ed. CRC Press, Boca Raton, FL, 1983-84.

${ }^{8}$ K. Y. Chia, S. G. Seshadri, and M. Srinivasan, "Notching Techniques Used in SENB Fracture Toughness," Ceram. Eng. Sci. Proc., 7 [7-8] 795-801 (1986).

"J. Wang, W. M. Rainforth, I. Wadsworth, and R. Stevens, "The Effects of Notch Width on the SENB Toughness for Oxide Ceramics,"I. Etw. Ceran. Soc. 10 [1] 21-31 (1992).

${ }^{20}$ P. Kofstad; p. 256 in Nonstoichiometry, Diffusion and Electrical Conductiv. ity in Binary Metal Orides. Wiley, New York, 1972.

"J. L. Smialek and G. M. Meier, "High-Temperature Oxidation"; pp. 293-326 in Superalloy 11. High Temperature Materials for Aerospace and Industrial Pow'er. Wiley, New York, 1987.

"2J. H. Wood and E. Goldman, "Protective Coatings"; see Ref. 21, pp. 